\title{
The pastoral care of preaching and the trauma of HIV and AIDS
}

F J Streets ${ }^{1}$

The Carl and Dorothy Bennett Professor in Pastoral Counseling, Wurzweiler School of Social Work, Yeshiva University, New York

City

Adjunct Associate Professor Pastoral Theology, Yale University Divinity School, New Haven, Connecticut

\section{ABSTRACT}

\section{The pastoral care of preaching and the trauma of HIV and AIDS}

There is within the history of Christian worship practices a long tradition of someone offering a sermon to those gathered for worship. The primary means for many Christians throughout the world of receiving Christian education and guidance is by listening to sermons. There is generally embedded in all Christian preaching some attempt on the part of the preacher to share a worldview based upon the his or her biblical and theological interpretation of the meaning of faith and their application to daily living. This article explores how the sermon can be a source of religious instruction and aspect of pastoral caring for those infected and affected by HIV and AIDS. The article also suggests that such sermons can be a form of advocating social justice for those who are stigmatized because of their HIV status. Note: The people mentioned in this article, are real but, their names, Rob, Inspiration and Pastor Able are fictitious for reasons of confidentiality.

"My Africa is fading and no one sees or cares that it is happening."

1 Rev. Dr. Frederick J Streets, former Chaplain of Yale University and Senior Pastor of the Church of Christ in Yale, USA is the Carl and Dorothy Bennett Professor of Pastoral Counseling at the Wurzweiler School of Social Work, Yeshiva University, New York City and adjunct Associate Professor Pastoral Theology, Yale University Divinity School in New Haven, CT. USA. He was a Fulbright Scholar in 2008 in the Department of Practical Theology at the University of Pretoria. His research focus was on the experiences of children and families living with HIV and AIDS. The author wishes to acknowledge the support of Professor Julian Muller, Chairperson of the Department of Practical Theology at the University of Pretoria for his support. 
Interview \#1, Nursing Sister, South Africa, 2008

\section{THE LIVED GLOBAL EXPERIENCE OF HIV AND AIDS}

Rob, a single African American man in his early 30's, sat in the pew during morning worship at his local church in the United States. His Pastor shared with the congregation that the sermon he was going to preach that morning would be one of several over a period of time addressing the issue of AIDS. Rob and his family had been active members of this church for several years and this was the first time

He heard his minister mention HIV and AIDS. His announcement surprised and frightened Rob. He was worried about what the minister would say about AIDS. In the early 1980"s so little was know about this disease. Rob knew at the time that most people who were aware of AIDS associated it with gay men. They also thought AIDS was primarily spread by the sexual behavior of gay men. Many people judge the sexual actions of gay people as promiscuous at the very least.

Inspiration, a young South African woman twenty-five years old, contracted HIV two years earlier from her boyfriend. She told me (Interview \#2, Streets, 2008) that during some of her most difficult moments living with HIV she wonders "why God did not like [me]". She said she knew that this is not true, that God does indeed love her but; feeling punished by God is how she described what it is like sometimes living with HIV. She avoids going to church.

Rob decided after hearing his Pastor's sermons about AIDS to make an appointment to see him. He disclosed when he met with him that he was infected with HIV. Rob's family knew of his conditions and was very supportive of him. The Pastor asked him why he had not shared this with him sooner. Rob replied that it was not until he heard the sermons about AIDS that he thought it would be "safe" for him to reveal his status to his Pastor. Feeling safe or punished, with all the other emotions running between these two, are what people infected and affected by HIV and AIDS experience who hear sermons being preached. Many people living with HIV and AIDS and those who care for and about them also carry the weight of this disease and they come to worship and sit in the pews and listen to sermons. There are also those infected and affected by HIV and AIDS who avoid attending church services and hearing sermons 
because they fear those with a HIV or AIDS status will be condemned through the sermons.

The advances in medical interventions and the use of antiretroviral drugs since the early 1980's enable people with HIV to live longer and healthier lives. These interventions which would have made Rob's living with HIV possible and less painful had not been developed in the 1980's during his ordeal. ARV medication taken by many people today who are living with HIV enables them to appear as though they are not carrying the virus. They however, do have to cope with living with HIV. This presents them with significant emotional and spiritual challenges. They often face these obstacles alone because they are afraid of what people will think of them if they knew they were HIV positive.

Note: According to www.AVERT.org (2008), there is an abundance of medical, scientific, sociological and theological information about HIV and AIDS available for example on the web, in libraries and health clinics. Recent publications of Jonny Steinberg's Three Letter Plague: A Young man's journey through a great epidemic published by Jonathan Ball Publishers in 2008 and Stephanie Nolen's Stories of AIDS in Africa published in 2007 by Portobello Books have brought more public attention to the HIV and AIDS crisis and epidemic.

The population of South Africa consists of people from diverse origins, cultures, beliefs and languages. There are 11 official languages spoken in South Africa and many ethnic and tribal groups comprising a total population of about 48 million people: Blacks are 79.6\%, Whites are 4.3\%, Indians and Asians are 1.2\% and Coloreds are $4.2 \%$

- By the end of 2005 approximately 51/2 million people were living with HIV in South Africa and about 1,000 deaths occurred every day.

- 320 thousand people died of an AIDS related death in 2005.

- The average life expectancy in South Africa is 54 years old; without AIDS it would be 64 years.

- It is estimated that HIV related patients account for $60-70 \%$ of medical expenditures.

- In 2006 21\% of teachers in South Africa were living with HIV. 
- Approximately 1.2 million children were orphaned by AIDS in 2005.

- Over 100,000 thousand orphaned children are designated Child Head of Household, which means they are the legal caretakers of their siblings and receive a government subsidy equivalent to about 28 dollars a month.

- About 260, 000 children below the age of 15 were living with HIV by the end of 2006.

\section{THE CLERGY AND HIV AND AIDS}

Members of the clergy also have fears about HIV/AIDS. One Pastor told me (Interview \#3, Streets, 2008) that "HIV/AIDS is a taboo! I think if I open the debate I will be fired.” Ministerial colleagues use to tell me that they would stand out in the hall of the room in the hospital when they went to visit a parishioner who had AIDS because they were afraid they would catch the disease if they touched or were in close proximity to the congregant they were calling upon.

Rob asked his Pastor while he was visiting him in the hospital “do you love me?" His minister said, "Yes, as a brother in Christ". Rob died a few days later. A new pastoral relationship between them emerged over time which ended with Rob's death. His Pastor learned from Rob how the physical, emotional and spiritual suffering of those infected with HIV/AIDS is compounded by the stigma many people assigned to those living with HIV/AIDS which make them feel like modern day lepers. Rob's congregation through his disclosure that he had AIDS came to better understand the impact HIV/AIDS has on those living with the disease, their family and the congregation. They initiated an AIDS outreach ministry in his honor and memory.

\section{PREACHING AS PASTORAL CARE AND THOSE LIVING WITH HIV AND AIDS}

There is a long and rich history of the power of Christian prophetic preaching about social justice and reform. The preaching of Dr. Martin Luther King, Jr., in the United States for example, motivated people to challenge racism and end legal segregation in America. Archbishop Desmond Tu Tu in South Africa through his preaching helped to rally the people there to end apartheid and established the Truth and Reconciliation Commission which has become an 
international model for peace making among former enemies. The sermons people hear at their weekly worship services and during revival gatherings can play a significant role in helping people living with HIV and AIDS to cope with this reality. Many people around the world infected and affected by HIV and AIDS experience the trauma of having this disease.

Everyone who delivers a sermon has to be mindful of the context in which the sermon is given. The culture, language, gender, age and history of the people to whom one preaches are for them the filters through which they interpret the meaning of what they hear in a sermon. Some of the ideas about trauma and preaching shared here I have reflected upon elsewhere (Streets 2005). The focus of this article is upon some of the important general things for those who preach about HIV and AIDS to consider about trauma and the traumatic affect of living with HIV and AIDS when preaching specifically about AIDS. These considerations will help the pastoral care dimension of preaching to emerge in a sermon in the speaker's effort to help those with HIV and AIDS to live with hope. It is important for us to remember that people living with HIV and AIDS and those who support them have much to teach us about resilience, human dignity and our need to care for one another. Addressing the issue of HIV and AIDS is also a way of emphasizing the social justice and transformation themes found within the Christian preaching tradition.

\section{HIV, AIDS AND TRAUMA}

Those who become infected with HIV are confronted with the task faced by anyone who experiences a traumatic event in their life. "Narrating one's life is about finding structure, coherence and meaning in life. Trauma, in contrast, is about the shattering of life's narrative structure, about a loss of meaning-the traumatized person has "lost the plot" (N van der Merwe and Gobodo-Madikizela 2008). $\mathrm{N}$ van der Merwe and Gobodo-Madikizela (2008) also suggest that trauma can be historical meaning a "single huge disaster, which can be personal (for instance, a rape) or communal (like a flood); or structural trauma, which refers to a pattern of continual and continuing traumas".

Taken form the Greek tramatos, meaning an injury from an external source (McGee 2005) remind us that "trauma is the physical, spiritual, and emotional wound caused by circumstances 
that are, in some way, a threat to life...Trauma changes our assumptions of identity, safety, and relationship with the world. Healing from trauma requires consciously knowing, as part of our life and self-concept, the unspeakable, the terrifying, and the incomprehensible realities of what people do to each other. Spirituality and trauma are both defining elements of our humanity. The response to traumatic circumstances is life preserving. It reflects the tenacity of human spirit and its powerful desire to survive in spite of threat and injury”.

Echoing a perspective on the meaning of trauma similar to McGee's (2005) N van der Merwe and Gobodo-Madikizela (2008) write: "The essence of psychological trauma is loss: loss of language, meaning, order, and sense of continuity. Trauma is a shattering of the basic organizing principles necessary to construct meaningful narratives about ourselves, others and our environment". Many people living with HIV and AIDS are traumatized by having the disease and depending upon the extent of their own psychological state, family and community and medical sources of support they may experience on-going trauma by being rejected by others and feeling helpless and hopeless due to their status in the community as a person who has HIV or AIDS.

\section{KNOW THYSELF}

It is important that members of the clergy who preach and/or provide pastoral counseling to others concerned about HIV and AIDS be as informed as possible about the nature, causes and how to prevent contracting or spreading the virus. It is also essential that the clergy examine their own attitudes, values and behaviors regarding their views about sex and sexuality, what it means to be a man, women or male or female child. The preacher may encounter a variety of perspectives others have about sex that are unfamiliar to them and which may make them feel uncomfortable. The views of those to whom they preach or provide counseling may be different from their own understanding of sexual behavior and HIV and AIDS.

\section{THE MEANINGS WE GIVE TO HIV AND AIDS}

HIV and AIDS means so many different things to people whether or not they are infected with the virus or see themselves as affected in some way by it. HIV and AIDS are for some people synonymous with death. It is a disease that carries very complicated social implications and has multiple factors and layers of meanings that are 
shaped by the context in which people live. We have an essential understanding of how the virus is contracted and spread from one human being to another. We know basically how the HIV virus works in the human body once it is contracted and the medical interventions needed to control the virus so that a person with HIV is protected from moving into having AIDS. The meaning we give to HIV and AIDS or having the virus or AIDS itself is far more challenging to discern and respond to than is our scientific knowledge about the disease. A sermon about HIV and AIDS has to address both our scientific understanding of and the meaning we give to HIV and AIDS. People live and experience HIV and AIDS at the level of what it means to them.

\section{HIV, AIDS IDENTITY AND INEQUALITY}

Women of child bearing age who have HIV or AIDS for example, have much to consider when deciding whether or not to have children. This struggle goes to the heart of what some of these women may consider as the core of their identity-to be a mother. What it means to be a woman, a mother and how to prevent mother to child transmission of HIV are questions faced by many women living with HIV and AIDS. Women have to answer questions like these and negotiate for themselves the complex cultural context which shapes these issues and their responses to HIV and AIDS and their relationship with men, their families, communities and others.

People with HIV or AIDS react differently to the trauma of having HIV or AIDS. They do not all have the same needs in their effort to cope with what has happened to them. Their response to being diagnosed with HIV depends upon their gender, personality, support of family and friends they receive and the socio-economic condition under which they live. Some will exhibit signs of depression or other emotional reactions such as anger, denial and despair as the reality of having HIV settles in. All persons with HIV need medical attention and counseling as they adjust to living with HIV.

Those who preach about HIV and AIDS need to be sensitive to the fact that some people with HIV contracted the virus through being raped or physically or sexually abused or tortured. In some situation they also witnessed loved ones and friends undergo similar experiences and they have seen some of them die as a result. The emotional struggles they have, although compounded by the 
conditions under which they contracted HIV may be secondary to their having HIV or AIDS. The circumstances under which they contracted HIV may have greater salience for how they feel about themselves, life and God than living with the disease itself.

The Pastor, through preaching about HIV and AIDS touches the memory someone with HIV or AIDS has of the context in which they became infected with HIV. It has been my experience that whenever I have preached on issues that emotionally resonate with people, the number of people requesting a pastoral meeting always increased during the week after I have preached the sermon. As preachers, we must be prepared for this possibility. The following suggestions are offered for your consideration when planning to preach about HIV and AIDS and reaching out to those in the congregation who are infected and affected by HIV and AIDS.

\section{SOME CONSIDERATIONS}

Pastors and those who preach will need to consider broadening their understanding of their role by learning some of the basic psychosocial methods of assessing someone's emotional and spiritual well-being and its relationship to the way a persons culture influences their self-understanding, ethnicity, gender role, sexual orientation, theology and worship, and how their faith helps them to live a meaningful life. Sharing ones feelings and experiences with a member of the clergy and understanding that there may be a link between thinking, emotions and physical well being are new perspectives, concepts and values for many people, including the clergy. Collaborating and learning from pastoral counselors and other mental health professionals in our community is a good way for Pastors and preachers to increase their knowledge and pastoral counseling skills. It is also an opportunity for counselors to learn from the clergy more about pastoral care and the important role that religion and spirituality plays in helping people to cope.

Persons who wish to tell their HIV or AIDS story are not necessarily further traumatized by doing so but, this can be for them an act of self-empowerment. The HIV and AIDS story of some people is not their life's story - there is more to who they are than the HIV they carry. They are not without strengths and capacities for living. Clergy, by allowing enough time for them to listen to those who may have been touched by the sermon who come to them seeking advice or help discover these traits of those seeking their 
help. It takes courage for people to come to a minister and share their pain. It is therefore important that they feel welcomed and that the Pastor's office and being with them makes the congregant feel safe. Learning to listen well to those who come to the Pastor underscores how much they can teach them about their pain and possible ways of successfully dealing with it. How people interpret an event and the meaning they give to it is crucial in understanding how they are dealing with that experience. Pastors can also be helpful by being a bridge for those in need to additional sources of social and psychological care available in their community. Knowing when and how to refer someone for additional support is an important part of pastoral care stewardship.

\section{EMPOWERMENT THROUGH BIBLICAL ASSOCIA- TIONS}

Some people who suffer from HIV or AIDS, associate themselves with the experiences of some of those found in the Bible such as Job, Jacob and Esau, Joseph, Judas, Peter, Ruth and Mary and Martha, Christian martyrs and, the suffering and death of Jesus Christ. Having HIV or AIDS affects their identity, their views and beliefs about God, and ideas of fairness and justice (example: the story of Job); family betrayal like in the stories of Jacob and Esau in Genesis 27 and 28 and Joseph in Genesis 37, devotion in the story of Ruth; and, the betrayal and denial of Judas Iscariot and Peter found in the Gospels; grief and hope as in the loss of Lazarus and Mary and Martha's response to his death, mercy and humiliation like Christ experienced while being judged and convicted and then executed to death on a cross. I have often heard Christians, Jews and Muslims alike say that "God does not put anymore (on them) than (they) can bear". These are some of the thoughts and images some people have in mind when they reflect upon their suffering and also while listening to sermons.

\section{WHO AM I NOW WITH HIV AND AIDS?}

People who have undergone substantial damage to their psyche and soul may answer a question or share a reflection by indicating what they would have said before the event and contrast it with how they see things now after contracting HIV and AIDS. One of the exceptions to this is of course children born with HIV. They are born with the disease and grow into the knowledge of what HIV and AIDS means and why they need certain medications to remain well. 
The trauma of becoming infected with HIV can divide a person's sense of self and of time and history. Wholeness for many of them is not about uniting these two half's but, discerning how to live with their sense of self and memories of how life was for them before contracting HIV and then after becoming infected with HIV. They now have to make sense of their new understanding of the world and themselves as a person living with HIV or AIDS. Understanding and acknowledging in a sermon the resilient capacity of people and providing suggestions on how they might find strength for their journey is a wonderful gift to those listening to the sermon who are infected and affected by HIV and AIDS.

Those living with HIV and AIDS experience a new understanding of normalcy, they have to reconsider the values by which to live and make choices and they struggle to redefine for themselves a sense of self agency or personal power. In some societies the number of persons living with HIV and AIDS is so huge until the majority of people living in those environments are all enduring the same basic struggle to survive in response to HIV and AIDS. Living with HIV and AIDS, watching people suffer and die from the disease is for them a normal way of life.

Imagine what it is like to have a virus around which you have to organize your life to get proper medical treatment, subscribe to a daily diet and medication regiment, learn to monitor how well you are feeling and functioning and negotiate with your partner what it means for the two of you to be intimate and to always practice safe sex measures. This would be difficult for many people to do living under the best of circumstances. Those living with HIV and in dire poverty and with little or no access to proper health care have these burdens to bear in addition to their illness. Women and women with children who live in male dominated cultures through out the world often have little or no control over dictating the terms of their sexual relationship with men. This inequity increases their chances of being sexually abused by men and contracting HIV.

\section{ALTRUISM, WORK AND SPIRITUALITY: SURVIVING WAR, VIOLENCE, AND TRAUMA}

The importance of altruism, work, and spirituality has been confirmed for me in my pastoral work with those traumatized by war and other forms of violence. They are applicable to people infected and affected by HIV and AIDS. Altruism, work, and spirituality are 
at the heart of people coping with the trauma of being diagnosed with HIV. Altruism is the type of therapeutic behavior that occurs when people help others, even when they have experienced some kind of devastation themselves. We as human beings have an enormous capacity to reach out toward one another. In many places around the world people with HIV and AIDS to the extent possible seek to help one another even, if it means sharing with one another their meager resources and limited strength.

People surviving with HIV or AIDS have a story of regret or shame about their physical condition. They may feel that they did not do enough for someone else in their same circumstance who suffered or died. These feelings of regret and shame most likely arise because altruistic behavior is a key mechanism for people traumatized by having HIV or AIDS to re-establish links between themselves, their shattered worldviews and other human beings.

Work is not just a function of being employed, producing a commodity, or providing a service in exchange for money or another good or service. In some communities unemployment is extremely high. Work or other socially productive activities such as performing chores, housework, making things with our hands and caring for children are other behaviors that contribute to people living with IHV and AIDS ability to cope with this reality. A complaint shared by all of the members of a HIV and AIDS weekly support group with whom I met recently was their lack of having a job. While having and remaining active on a job is critical to resisting the emotional distress of living with HIV or AIDS, participating in the daily activities of life is also therapeutic. No activity is too small or too insignificant. While it has been discovered that for traumatized people work of various forms is the world's most important antidepressant, it is an under-appreciated, under-utilized therapeutic activity for people living with HIV and AIDS.

Spirituality is also an aspect of being human that cannot be reduced to its parts. Every person is worthy of respect and deserves to receive care, regardless of those things about them which we find objectionable. A person's sense of altruism, capacity to work and being a creation of God whom God loves are important ideas for a sermon dealing with people living with HIV and AIDS to emphasize.

HIV and AIDS challenge our fundamental beliefs and values about ourselves, life itself, and our understanding of other people. It 
shakes or destroys the confidence those living with HIV or AIDS have in their values and beliefs to provide them with meaning for living. Religion and spirituality have been positive forces in the lives of many of those who are surviving with the trauma of being infected or affected by HIV and AIDS. They derive meaning for living from their sense of spirituality in addition to altruism and work.

Those living with HIV/AIDS who are actively engaged in spiritual practices were the most resistant to developing the long range impact of being depressed because of their HIV/AIDS status. Prayer, meditation, traditional healing and other spiritual rituals and practices are widely prevalent in the homes and communities of many living with HIV/AIDS. A sermon can lift up the many ways that altruism, work and religious practices where encouraged by Jesus in some of the parables and stories about people who were marginalized due to their mental or health state. His encounter with people, particularly women, affirmed and helped them to reflect upon how they chose to live and what the sources were that sustained and gave them hope and meaning for living. In the sermon the preacher can ask listeners directly or indirectly, what sustains and gives them hope?

There are risks involved in putting into words the trauma of living with HIV and AIDS and we take risks when we maintain silence about the emotional and physical pains caused by having HIV or AIDS. Preaching about this topic means that the preacher is able through the sermon to guide those listening along their journey toward spiritual and emotional well-being.

\section{PRIVATE TOPIC VS SOCIAL PROBLEM}

HIV and AIDS is a disease of intimacy. The transmission of the disease by one person who has the virus to another occurs when they engage in unsafe sex practices or other activity, such as the sharing of intravenous needles, in which the blood, semen or other bodily fluids of the infected person enters into the blood stream of the other. One cannot talk about HIV and AIDS without causing people to consider their attitudes, beliefs and sexual practices. In many societies and cultures it is taboo to publicly deal with sex and sexuality. These matters are thought by many people to be personal and only discussed in private. 


\section{THE PASTOR'S CHALLENGE AND RESPONSE}

Pastor Able was aware of these perspective people had about HIV and AIDS as he struggled for several weeks with how to present to his congregation through his sermons the issue of HIV/AIDS. He decided that the aim of his sermon would be to inform people about HIV/AIDS and motivate them to have a compassionate response to those living with and affected by the disease. He approached HIV/AIDS in the sermon first by sharing the basic facts about the disease-how prevalent it was in his community, how it is transmitted and the precautions one needed to take to decrease the chances of contracting the virus. He then spoke about the impact of the disease on the persons who have it and how that affects her family and friends. He gave attention to the stigmatization endured by people with HIV/AIDS. The focus of his sermon was also upon offering some suggestions about the attitudes and values he felt as Christians, they should have about HIV /AIDS. He used these as principles as a guide to outlining an outreach ministry of the church to people living with and infected by HIV/AIDS. His theological basis for his presentation was the admonishment of Jesus to love and care for those who are sick and most vulnerable found in the Gospel of Matthew chapter 25.

To his surprise and delight the sermon was well received by the congregation. It open-up a conversation among the members and leaders of the church about HIV/AIDS. This challenged the silence and denial that often surrounds the disease. Pastor Able learned from members of his congregation that they too were living with the reality of HIV/AIDS in their family and work place as they carried the burden, often in silence and alone of a loved one or colleague who was suffering from the disease. They too were looking for ways to strengthen their spirits and exercise their faith in response to HIV and AIDS. These conversations with members of his church led the congregation to providing updated information about the causes and prevention of HIV/AIDS to its members, linking with other congregations and organizations that provided HIV/AIDS resources and to establish a ministry of helping those living with HIV/AIDS to receive the support and medical attention they needed to better cope with the disease and its impact upon them.

I think it is more important for a sermon to emphasize compassion and not judgment toward those living with and affected by HIV/AIDS. Not everyone who is infected with HIV became so 
because of engaging in risky sexual behavior. We did not know in the early days of the disease as much as we do now about how the virus was transmitted nor were there measures available to test blood for the presence of the virus. This resulted in some people contracting HIV/AIDS through blood transfusions. There are many other reasons and ways people unknowingly become infected with the virus in spite of HIV/AIDS awareness education and prevention programs. Some people who are informed about the disease may still make choices that lead to their becoming infected. Regardless of how and why a person becomes infected with the HIV virus they are not to be further victimized by being blamed for their condition. Helping them to live responsibly with the virus is more important than reminding them of their liability for having contracted the disease. The pastoral care tasks commonly referred to in the West are healing, guiding, sustaining and reconciling and liberating or empowering people. These are best nourished in others as they listen to a sermon given by a preacher who conveys to them through his or her sermon an attitude of welcome and hospitality. This is what Jesus did as he preached and taught the meaning of God's love to those who were sick or marginalized by their ethnicity (the Samaritan) or gender (woman at the well).

\section{SUMMARY}

People with HIV /AIDS are engaged in the process made extremely difficult by their having the disease, of recreating an image of themselves and redefining their meaning of wholeness. Preachers who are empathetic to their plight can use this feeling to enter into ways of thinking that will enable them to unlock through preaching the loving and healing power of the Christian message for those who are suffering with HIV/AIDS. People living with HIV/AIDS need new images of themselves that the disease would otherwise destroy and violate their earlier understanding of themselves, reality and truth (McGee 2005). This means being able to reverence one's life by the vitality it is given by the medications for HIV even though having the disease may at times cause them distress (McGee 2005).

Like pastoral counseling, according to Dittes (1999), (I have substituted the word "preaching" where Dittes uses the word "counseling”), pastoral preaching about HIV/ AIDS "cannot change the facts of poverty or other injustice, abuse, oppression, alcoholism, psychosis, cancer, atheism or depression. But [pastoral preaching\} is profoundly committed and effective in energizing people to address 
such facts, changing what they can and coping creatively as they must...Pastoral [preaching] aspires to enable people to take their place as responsible citizens of God's world, as agents of God's redemptive hope for that world...To reclaim commitment and clarity, to beget faith, hope, and love, to find life affirmed-this is the conversion of soul that sometimes happens [when people hear pastoral preaching]".

\section{CONCLUSION}

There are multiple factors that contribute to the global spread of HIV/AIDS. Ignorance about or denial that the disease impacts our life in some situations and the addition of abject poverty or the lack of medical resources in others, along with how people who are infected or affected by HIV/AIDS are stigmatized, each have to be a part of the preacher's attention when he or she gives sermons on HIV/AIDS. In some ways these dimension are easier to address in sermons on HIV/AIDS than the more vexing matter of: (a) understanding how and what motivates people to change their behavior that reduces their risk of contracting or spreading HIV/AIDS and (b) dealing with compound their suffering from the disease compounded by their being marginalized and discriminated against because of their health status. Human behavioral change reflects a matrix of what constitutes our values, norms, customs and our ethical and moral compass (Nicolson 2008). These are shaped by our identity, social, political, ethnic, gender, economic and cultural histories and moments in time.

Some people deny the reality and impact of HIV/AIDS. A discussion of some of the many social, cultural, political, economic and individual reasons why some people deny that HIV/AIDS exist or is a global health problem are beyond the scope of this paper. In some communities, however, the denial of HIV/AIDS existence or its impact on people and communities around the world seems to function differently than the traditional meaning of the way denial functions for some people as their psychological coping mechanism. Denial is the psychological process of ignoring, or failing to acknowledge to one's self or to others aspects of external reality or one's own experience even if these aspects are evident to other people (Psychodynamic Diagnostic Manual 2006). I have observed that some people minimize the consequences of being infected or affected by HIV/AIDS as a means of warding off despair. This nuance function of denial enables them to face what they are willing 
to see as the reality of HIV/AIDS in their life. A fundamental aim of preaching with people in the audience or congregation concerned for whatever reasons about HIV/AIDS is to alleviate their sense of misery and wretchedness-to confront their sense of despair.

All behavior is a form of communication that attempts to speak of those things that gives us meaning and purpose as well as about those matters that haunt and horrify us. Religious beliefs and spiritual practices are some of the ways many people try to make sense and speak of their experiences and work at reconciliation coming into a sense of peace with themselves and who or what they perceive as their enemy. We do all of this in an effort to further write the narrative of our life. This task is even more imperative after we have been wounded by the trauma of contracting HIV/AIDS. The experience of a woman member of the clergy I interviewed in South Africa (Streets, Interview \#4, 2008) is not unusual for many clergy:

With my dealings with HIV and AIDS in South Africa, I have been introduced to a world I knew existed, but didn't really understand. I feel now that this should be the number one priority for the churches in South Africa, as enormous ethical issues underlies this epidemic and the spread thereof...in the African churches the issue of HIV is mostly condemned...I do feel that there is more work to be done and various aspects of human suffering brought on by this disease that need the attention of the ministry...It's a circular motion: if the churches can get more involved in the care of the patients, education will follow and as such also the re-institution of moral values regarding sex and the abuse of women (or the disregard)...AIDS have brought to our attention the extreme level of poverty and crime which are directly spreading the disease and which is infiltrating our country and people's lives".

All who preach and listen to sermons know something about suffering, sin and evil. Minister in communities ravaged by HIV/AIDS can identify with the above quote form a clergy colleague. We come out of a broken world or situation to hear (and deliver) sermons. The word "trauma” implies injury or wound. There are endless ways we can hurt other people but, pain is not all there is about the world and our living in it. We have, since the beginning of humankind, found ways to overcome despair and our feeling humiliated and to cope with and heal our wounds and flourish. Preaching and hearing sermons are two of the ways we have endured life changes and hardships. 
There are a number of variables that help to shape the perspectives of a preacher's sermon. His or her critical explanation or interpretation of the text is based upon the preacher's understanding of the historical and cultural context in which the scriptures was written. The preacher must be aware of what the faith tradition he or she represents has taught as the meaning of the text. They are to express as best as possible to the congregation in the sermon where and why he or she agrees and differs with that viewpoint. The preacher conveys through the sermon his or her understanding of how the meaning of a text applies to the lived experience of the listener. These considerations of the preacher when preparing and delivering a sermon mean that preaching is always subjective and contextual. In the act of preaching the speaker attempts to help people gain insight about themselves or a life situation in light of the beliefs and teachings of the church and to engage the listeners in a reflective process of discerning what it means for them to live faithfully and meaningfully as they deal with the vicissitudes of life. This is always a goal of preaching whether or not the objective of the sermon is to primarily inform, instruct, inspire and/or to motivate those who hear the sermon to become a certain kind of person or act in particular ways. The following reflection on the meaning of Baptism and the $29^{\text {th }}$ Psalm, for example, is a pastoral perspective a preacher can take in a sermon that addresses HIV/AIDS (Streets 2009).

Our Baptism does not prevent us from later on in life entering into troubling waters. Some of our troubles we bring upon ourselves while others just seem to find us. It is a naive understanding of faith to think that because we have been baptized that we would be exempt from some of life's hardships. Luke records (4:1-11) for example, that after Jesus was baptized he was immediately led into the wilderness. Perhaps he was so overwhelmed by the experience that he sought a secluded place to further clarify to whom and what he was dedicating his life. Regardless of what motivated him to go into the wilderness there he was challenge to discern the values by which he would live his life.

Many of the psalms were written to be recited or sung by people gathered for worship. People come to worship not just to find or experience God. God can be found in many places. They come together and by sharing their journey of faith and drawing strength from one another they become a congregation. The voice of God in 
the $29^{\text {th }}$ psalm is symbolic of the thunder and associated with the power of the strong winds and rain of a serious storm. The Psalmist attempts to assure the people gathered of God's care of them during the wilderness places and storms of life. He declares to them that "the Lord will give strength to his people and bless them with peace" (verse 11). Strength to endure the storms of life and reassurance of the peace that follows echoes the shepherding spirit of God found in Psalm twenty-three. I visited with a group of people, many of whom are living in poverty in a small community in South Africa. They met to give one another support as people infected or affected by HIV/AIDS. One of their exercises was to break into small groups and write their own interpretation of a biblical passage. They compared notes when they reassembled as a whole group and collectively composed their version of Psalm 23 which reads:

The Lord loves and protects us even though we are HIV+

The Lord is Alpha and Omega.

$A R V$ 's (antiretroviral drugs) do not work because we are clever, but with the grace of God.

The situation we are in, it shows that God will take us to green pastures.

Even though we are HIV+, we will not fear death.

He prepares even when neighbors look at you through their windows saying: "when are you dying”?

He gives us strength to go on.

Even if the going gets tough, he is our shelter.

Through God, everything is possible.

This interpretation of the $23^{\text {rd }}$ psalm expresses the courage and faith of ordinary people who live everyday under conditions of poverty and poor health unimaginable by many. The faith and spirit of the psalmist permeates the Book of Psalms. The inspiration of psalm 29, like that of 23, flows down through the centuries and connects to the spirit of people whose faith and courage remind us that the same spirit lives in us all.

The baptism of Jesus signaled the beginning of his long journey of becoming for us the strength and hope we would need for the path upon which we travel. It is reassuring to know that we can find strength and direction in a wilderness and peace will follow a 
storm. God is the creator and sustainer of all things including human life. In worship we praise God for who God is and for whom God has become to us. David seemed to have a keen understanding of this and our human need to connect with God. God was personal to David. So much of Christian teaching and preaching makes faithful living seem joyless and always struggle. David's spirit of faith conveyed in his writings reflect his personal experiences, growth and the nature of his theological insights about how we may discover the mercy and goodness of God and the sense of freedom and power that comes from doing so. He strove to share his faith with those who came to worship God. God's love has for the Christian community become present to us through Jesus Christ. God has assured those who believe in him by resurrecting Christ from the dead that we need not even fear death itself or those things that remind us of our mortality and place in the nature of all created things. We can proceed on our way trusting in Him who has become our way, truth and life. Believing this can transform us and give us a new direction and purpose for living.

Grief, mourning, separation, awe and joy are realities of life. Sometime we feel that we have too many losses, too much sadness and enough separations and not enough wonder and joy in life. When people gather to worship God they are also seeking confirmation that things will be well. This is especially true if they have just experienced or are anticipating facing a storm in their lives. This confirmation often comes through our commitment to give witness as best we can to what we believe it means for us to be a Christian. Faith at some point require that we not so mush as surrender ourselves to God, as though we can no longer remain, like a criminal on the lamb, but to embrace and trust God for whom the Christian community has witnessed God in Christ to be. Hope emerges from the texture of these experiences and gives wings to our dreams, integrity to our actions, strength and substance to our efforts to be a witness and agents of God in the world. God does not render us unknown, unfulfilled and separated from God's love. Whatever lies ahead of us there is also God who promises to be with us always. This faith is not ours to possess alone but by serving others we share the hope of Christ. This hope is born out of our love for God we have come to know through Jesus Christ, others and the communities of which we are a part. Congregations hope for us and pray for us and believe for us when we have lost hope or feel that we 
can no longer pray or believe enough in God to rejoice his name. They remind us through honest worship that during those moments of fear, anguish and doubt we are not alone. This presence, blessing, and peace of God celebrated in Psalm 29 were also announced at the baptism of Jesus and accompanied him on his way. And so they can by our faith be with us.

The preached word, like a mustard seed, can be planted in those who hear it and become for them fruits of strength for living with HIV/AIDS and to recover from having been harmed by the stigma of having the virus. The nature of this seed is its healing agency and it has a chance to become for someone who has been injured a source healing. Pastors and preachers may not have the power to heal. They do have an invitation embedded in their calling from God to plant a seed of hope through their preaching of the Good News. This nurturing of hope is what Rob and Inspiration and others like them; men, women, children and families around the world infected and affected by HIV/AIDS look to receive from hearing sermons and the healing ministries of churches.

Most religious traditions promote the physical, mental and spiritual health of people. They also advocate that we seek justice, show mercy and walk humbly before God and. that we have an ethical and moral calling to heal the sick, feed the hungry, visit those in prison, and show compassion, especially to children. The role of the church around HIV and AIDS and children encompasses three areas: health education, direct health services and advocacy for good policies regarding the welfare, care and safety of children. Children are human beings and not little adults. The following suggestions are in keeping with this mission of the church and recognize the significant amount of caring of children and families infected and affected by HIV and AIDS done by members of religious communities and churches in South Africa:

(1) It is important for church and other religious leaders to have a developmental understanding of children and their needs.

(2) Programs and activities addressing the best interests of children will have to be planned with an understanding of the emotional, physical and spiritual growth, needs and stages of children. What it means to love, care for and discipline a child has to be explored with the child's parents. 
(3) Church leaders should encourage an understanding that those infected and affected by HIV and AIDS are not being punished by God. We need to remind our congregations and each other that we remain children of God and brothers and sisters to one another regardless of the status of our health or abilities. How difficult would it be to believe in a god that punishes children?

(4) The vulnerability, stigmatization, hostility, shame, guilt and humiliation experienced by some people infected and affected by HIV and AIDS, especially children needs to be challenged by religious people by their providing compassionate care of and witness to the experiences of those suffering from HIV and AIDS. There are over 40 accounts in the New Testament of Jesus being a model for us in doing this kind of ministry of healing. It would be an important contribution of the church if its leaders provided a theology of sexuality and of the body as it relates to children which means that God demands of us that we see children as precious and needing protection and that we promote amongst each other as adults the sanctity of the body and teach children the same and model this lesson for children.

(5) Churches and other faith based organizations could establish day care centers for children infected by HIV and AIDS. Its programs and curriculum would include parenting skills, health care information and promotion for the children and their families and nurture the self-esteem of the children. Church could develop programs for recruiting and training volunteers to become parents for the parentless who would support children who have lost their parents.

It is helpful and important for people of faith to remember that their care of and for children and families who are infected and affected by HIV and AIDS are acts of transforming them from seeing themselves as defiled to people living with a sense of hope, dignity and pride God wishes for us all.

It is important not to deny the global pandemic that is HIV and AIDS. The suffering of those who are infected and affected by this disease is compounded by their being stigmatized as modern-day lepers. The fact is that we are all affected by HIV and AIDS. We learned from another culture on the other side of the globe, what must be urgently attended to locally and in our own country. In many places around the world those who are poor and women and children 
are most vulnerable to contracting HIV. This is also true for those living in poverty, minorities and for women and children in the United States. There are approximately 1.2 million people living with AIDS in the US. African Americans are 13\% of the population but are $48 \%$ of new HIV or AIDS diagnosed cases in 2005. It is the leading cause of death among Black people between the ages of 2544 in 2004.

HIV and AIDS is one of the most complex diseases we face today. It affects every aspect of human life. Our response to it is a measure of our humanity and will influence the overall quality of life of everyone on the planet.

\section{Consulted literature}

Dittes, J E 1990. Pastoral Counseling: The Basis. Louisville, Kentucky: Westminster John Knox Press.

Merwe, C N van der and P Gobodo-Madikizela 2008. Narrating Our Healing: Perspectives on Working Through Trauma. Newcastle, UK: Cambridge Scholars Press.

McGee, T R 2005. Transforming Trauma: A Path toward Wholeness. Maryknoll, New York: Orbis Books.

Nicolson, R 2008. Persons in Community: African Ethics In A Global Culture. South Africa: University of KwaZula-Natal Press.

PDM Task Force 2006. Psychodynamic Diagnostic Manual. Silver Spring, MD: Alliance of Psychoanalytic Organizations

Streets, F J 2005. Preaching and Trauma. The Living Pulpit. OctoberDecember, 2005. Yale University Press.

(2008) Interviews \#1, \#2, \#3 and \#4, South Africa.

-, 2009. A commentary on Psalm 23, in Bartlett, D L \& Taylor, B B (eds). Feasting on the Word. Louisville: Westminster John Knox Press (forthcoming). 